\title{
Analisis Kesulitan Belajar Siswa pada Materi Geometri di Sekolah Dasar
}

\section{Irfan Fauzi and Andika Arisetyawan ${ }^{2}$}

1,2Sekolah Pascasarjana Universitas Pendidikan Indonesia

Corresponding Author: If96@upi.edu',Andikaarisetyawan@upi.edu²

DOI: http://dx.doi.org/10.15294/kreano.v1 1i1.20726

Received : August 21 2019; Accepted: April 23 2020; Published: June 12020

\begin{abstract}
Abstrak
Geometri adalah cabang matematika yang diajarkan dengan tujuan agar siswa dapat memahami sifat-sifat dan hubungan antar unsur geometri serta dapat mendorong siswa untuk dapat berpikir secara kritis dan memecahkan masalah dalam kehidupan sehari-hari. Penelitian ini bertujuan untuk menganalisis kesulitan siswa kelas 4 SD Negeri Asmi 033 Kota Bandung dalam menjawab soal geometri. Penelitian ini menggunakan studi eksploratif dalam bentuk tes uraian tertulis pada materi geometri yang diberikan kepada 26 siswa SD Negeri Asmi 033 Kota Bandung. Hasil analisis menunjukkan bahwa terdapat kesulitan yang dihadapi siswa dalam menjawab soal geometri, kesulitan tersebut diantaranya adalah (1) siswa kesulitan dalam penggunaan konsep, (2) siswa kesulitan dalam penggunaan prinsip, dan (3) siswa kesulitan dalam menyelesaikan masalah-masalah verbal. Hasil penelitian ini dapat dijadikan bahan pengembangan permasalahan geometri, khususnya pada materi keliling dan luas bangun datar di masa yang akan datang.
\end{abstract}

Kata Kunci: Matematika; geometri ; kesulitan belajar

\begin{abstract}
Geometry is a branch of mathematics taught with the aim that students can understand the properties and relationships between elements of geometry and can encourage students to be able to think critically and solve problems in everyday life. This study aims to analyze the difficulties of fourth grade students of SD Negeri Asmi 033 Bandung City in answering geometry question. This study used an exploratory study in the form of a written description test on the geometry material given to 26 students of SD Negeri Asmi 033 Bandung City. The results of the analysis show that there were difficulties faced by students in answering geometry questions, such difficulties were (1) students difficulty in using concepts, (2) students difficulty in using principles, and (3) students difficuly in solving verbal problems. The result of this study can be used as material for the development of geometry problems, especially in the material of circumference and area of plane (geometry) in the future.
\end{abstract}

Keywords: mathematics; geometry; plane (geometry); difficulty learning

\section{PENDAHULUAN}

Keterampilan abad 21 sangat mempengaruhi diskusi diberbagai bidang khususnya dalam pendidikan, konten yang sangat penting dan harus diajarkan dalam mencapai keterampilan abad 21 adalah pendidikan mate- matika (Gravemeijer et al., 2017). Matematika sudah diajarkan dari mulai pendidikan dasar sampai pendidikan tinggi. Menurut Baykul dalam (Unlu et al., 2017) matematika adalah alat yang sangat penting dipelajari oleh siswa, matematika digunakan untuk memecahkan masalah dalam sains dan kehidupan sehari- 
hari, di lain hal, matematika akan membantu siswa berfikir secara kreatif dan kritis dan juga dapat memahami dunia. Sementara itu, Tujuan pembelajaran matematika menurut Kemendikbud 2013 (Fasha et al., 2018) yaitu (1) meningkatkan kemampuan intelektual, (2) membentuk kemampuan siswa dalam menyelesaikan suatu masalah secara sistematik, (3) memperoleh hasil belajar yang tinggi, (4) melatih siswa dalam mengkomunikasikan ideide, khususnya dalam menulis karya ilmiah, dan (5) mengembangkan karakter siswa.

Kenyataannya bahwa matematika dipandang sebagai mata pelajaran yang sulit dipahami oleh siswa, hal ini juga didukung dengan banyaknya siswa yang tidak menyukai pembelajaran ini (Ricks, 2009), ditambah dengan laporan OECD tahun 2014 bahwa hasil riset PISA pada tahun 2012 menunjukkan Indonesia menempati urutan peringkat ke 64 dari 65 negara dengan skor 375, lebih lanjut dijelaskan bahwa 75,7 \% siswa Indonesia memiliki kinerja yang rendah dan hanya mampu mengerjakkan soal yang sederhana, dan hanya 0,1\% siswa yang mampu menyelesikan pemodelan matematika yang menuntut keterampilan berpikir dan pemecahan masalah (Nur \& Palobo, 2018). Masalah ketidaksukaan siswa pada pembelajaran khususnya matematika nampaknya akan berdampak pada rendahnya semangat dan motivasi belajar, tidak dapat menguasai materi pelajaran, bahkan menghindari mata pelajaran, mengabaikan tugas dari guru lsehingga terjadi penurunan nilai belajar dan prestasi belajar siswa (Mufarizuddin, 2018). Sementara itu, Cooney (Yusmin, 2016) mengatakan bahwa kesulitan belajar matematika diklasifikasikan ke dalam tiga jenis diantaranya adalah (1) kesulitan siswa dalam penggunaan konsep, (2) kesulitan siswa dalam penggunaan prinsip, (3) kesulitan siswa dalam menyelesaikan masalah-masalah verbal. Kesulitan tersebut disebabkan karena pembelajaran matematika selama ini disampaikan kepada siswa secara informatif, artinya siswa hanya memperoleh informasi dari guru saja sehinga derajat kemelekatannya juga dapat dikatakan rendah. Maka peran guru dalam mengajarkan matematika sangat penting, guru harus dapat mengajarkan pembelajaran yang bermakna, karena hal ini akan berpen- garuh pada konteks pemaknaan yang diperoleh siswa (Turmudi, 2008). Menurut Hill et al., (2008) guru perlu melibatkan siswa dalam setiap mata pelajaran, karena hal itu merupakan aspek terpenting dalam kompetensi profesional guru. Peran inilah yang harus diajalankan guru dalam membangun pembelajaran matematika agar tidak terjadi kesalahan yang dilakukan oleh siswa.

Geometri merupakan cabang dari matematika dan menjadi salah satu materi pelajaran dalam matematika di sekolah dasar. Geometri sangat berkaitan dengan pembentukan konsep abstrak. Pembelajaran ini tidak bisa hanya dilakukan dengan transfer pengetahuan atau ceramah saja, tetapi harus dilakukan dengan pembentukkan konsep melalui rangkaian kegiatan yang dilakukan langsung oleh siswa (Nurhasanah et al., 2017).

Dalam mempelajari geometri, siswa membutuhkan suatu konsep yang matang sehingga siswa mampu menerapkan keterampilan geometri yang dimiliki seperti menvisualisasikan, mengenal bermacam-macam bangun datar dan ruang, mendeskripsikan gambar, menyeketsa gambar bangun, melabel titik tertentu, dan kemampuan untuk mengenal perbedaan dan kesamaan antar bangun geometri (Muhassanah et al., 2014). Dalam memahami hubungan-hubungan diantara bangun geometri, siswa sudah diajarkan bagaimana mencari keliling dan luas bangun datar di kelas 4, pembelajaran ini berkesinambungan dari mulai mengidentifikasi sifat-sifat segi banyak, lalu kemudian menemukan keliling dan luas beberapa bangun datar (persegi, persegi panjang, segitiga, jajargenjang, trapesium, belah ketupat dan laying-layang), setelah siswa mempelajari bangun datar, siswa akan mendapatkan pembelajaran geometri kembali di kelas 5 tepatnya materi bangun ruang, sehingga dalam hal ini materi keliling dan luas bangun datar menjadi prasyarat dalam mempelajari materi bangun ruang di kelas 5 .

Di sisi lain, porsi materi geometri sangat besar dibandingkan dengan materi yang lainnya. Dalam kompetensi dasar matematika di sekolah dasar yang disusun oleh kemendikbud dalam Permendikbud nomor 37 Tahun 2018 bahwa presentase materi geometri di 
sekolah dasar berkisar 40-50 \%. Hal inilah yang membuktikkan bahwa geometri bukan hanya bagian penting dalam matematika, tetapi juga dalam kehidupan sehari-hari (Cherif et al., 2017; Panaoura, 2014; Rofii et al., 2018) alasannya adalah karena geometri dianggap bidang yang dapat mendorong visualisasi, intuisi, pemikiran kritis, pemecahan masalah, penalaran deduktif, argument dan bukti logis siswa (Jupri, 2017; Seah, 2015). Akan tetapi dalam pembelajarannya terkadang siswa juga sangat sulit untuk memahami materi geometri (Fauzi et al., 2019; MdYunus et al., 2019) hal ini disebabkan karena kesulitannya siswa dalam membentuk kontruksi nyata yang akurat, membutuhkan ketelitian dalam pengukuran, membutuhkan waktu yang lama dan bahkan banyak siswa yang mengalami hambatan dalam pembuktian terhadap jawabannya (Noto et al., 2019).

Hasil wawancara yang dilakukan dengan guru kelas 4 SD Negeri Asmi 033 Kota Bandung bahwa (1) materi geometri mempunyai banyak rumus sehingga hal ini sulit dipahami oleh siswa, (2) Siswa yang pemahamannya masih pada tahap operasional konkret harus diajarkan materi geometri yang kompleks yang didalamnya terdapat banyak simbol dan operasi yang formal, hal inilah yang menjadi kesulitan siswa dalam memahami materi geometri. Maka dalam penelitian ini peneliti akan menganalisis kesulitan belajar siswa pada materi geometri khususnya pada keliling dan luas bangun datar di SD Negeri Asmi 033 Kota Bandung, penelitian ini diharapkan dapat dijadikan sebagai bahan pengembangan permasalahan geometri, dan digunakan untuk membuat rencana pembelajaran oleh guru, karena rencana pembelajaran seharusnya dibuat berdasarkan kesulitan belajar siswa, maka dalam hal ini guru perlu memahami kesulitan belajar dan alur berpikir siswa berkaitan dengan materi geometri khususnya pada keliling dan luas bangun datar, sehingga rencana pembelajaran yang dibuat sesuai dengan kondisi nyata yang dialami siswa.

\section{METODE}

Penelitian ini menggunakan pendekatan kualitatif, menurut Locke (Creswell, 2015) penelitian kualitatif adalah penelitian interaktif yang didalamnya peneliti terlibat dalam pengalaman yang berkelanjutan dan terus menerus dengan partisifan, keteribatan inilah yang nantinya akan memunculkan serangkaian isu-isu yang strategis, etis, dan personal dalam proses penelitian kualitatif. Sedangkan menurut Lestari \& Mokhamad Ridwan Yudhanegara (2015) bahwa penelitian kualitatif merupakan metode-metode untuk mengeksplorasi dan memahami makna yang oleh sejumlah individu atau sekelompok orang dianggap berasal dari masalah sosial atau kemanusiaan, maka pendekatan kualitatif sangat cocok digunakan dalam mengungkap berbagai fenomena sentra yang muncul dalam penelitian ini. Penelitian ini menggunakan metode deskriptif eksploratif melalui tes tertulis, wawancara dan catatan lapangan. Menurut Arikunto (2006) bahwa penelitian eksploratif merupakan penelitian yang bertujuan yang tujuannya untuk menggali secara luas dan mendalam tentang sebab-sebab atau hal-hal yang mempengaruhi terjadinya sesuatu. Subjek yang digunakan dalam penelitian ini adalah 26 siswa SD Negeri Asmi 033 Kota Bandung. Instrumen yang digunakan dalam penelitian ini adalah tes uraian tertulis yang mengacu pada silabus pembelajaran matematika di kelas 4 sekolah dasar.

Pengumpulan data dilakukan sebagai berikut (1) Siswa diminta untuk menjawab soal tes uraian tentang keliling dan luas bangun datar dalam waktu 25 menit secara individu, (2) pengerjaan siswa dalam lembar soal yang berbentuk coretan-coretan menjadi data pendukung hasil tes tertulis, (3) peneliti mengambil beberapa jawaban siswa yang mengalami kesulitan untuk di wawancara.

Analisis data yang dilakukan pada penelitian ini dilakukan dengan dua tahap. (1) mengidentifikasi dan mengelompokkan kesalahan-kesalahan siswa dalam menjawab soal geometri yaitu keliling dan luas bangun datar, (2) Menganalisis lebih lanjut jenis kesalahan-kesalahan siswa berdasarkan teori Cooney.

\section{HASIL DAN PEMBAHASAN}

Pada saat observasi dilakukan di SD Negeri Asmi 033 Kota Bandung, peneliti memberikan soal berbentuk gabungan bangun datar 
untuk kemudian siswa cari tahu keliling dan luasnya. Secara keseluruhan, siswa mengalami kesulitan ketika dihadapkan dengan soal yang berbeda. Biasanya guru hanya menyajikan konteks soal yang biasa yang sifatnya hanya mengingat sebuah rumus yang telah diberikkan guru.

Dari 26 siswa yang menjawab soal keliling bangun datar, hanya 4 orang yang menjawab dengan benar, dan 22 orang menjawab dengan keliru, ini menunjukkan bahwa presentase siswa dalam menjawab soal dengan benar adalah $15,3 \%$ dan presentase siswa yang menjawab dengan keliru adalah 84,7 $\%$, sedangkan untuk soal luas bangun datar, hanya 1 orang yang menjawab dengan benar, dan 25 orang menjawab dengan keliru, artinya presentase siswa dalam menjawab soal bangun datar dengan benar hanya 3,8 \% dan presentase siswa yang menjawab dengan keliru adalah $96,2 \%$.

Terlepas dari rendahnya presentase siswa dalam menjawab soal geometri diatas, ada beberapa hal yang perlu dicatat terkait dengan jawaban siswa yang keliru, jawaban ini tentunya dilatarbelakangi oleh kesulitan siswa dalam menghadapi soal geometri tersebut. untuk menganalisis jawabannya, maka terlebih dahulu akan disajikan bentuk soal yang diberikan kepada siswa. Bentuk soalnya dapat dilihat pada Gambar 1.

Tentukan Keliling dan Luas Bangun Datar dibawah ini!

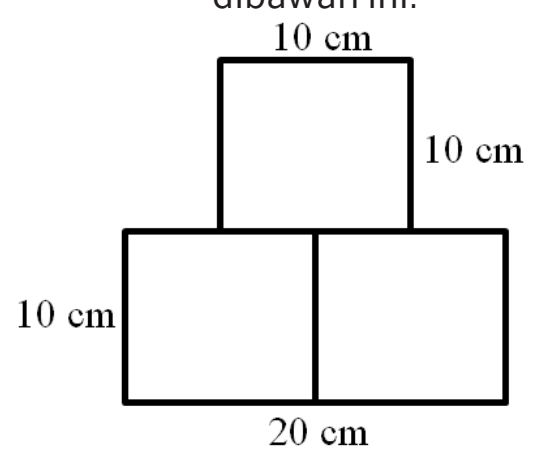

Gambar 1. Soal Keliling dan Luas Gabungan Bangun Datar.

Secara keseluruhan akan disajikkan berbagai bentuk kesalahan-kesalahan yang dilakukan oleh siswa pada saat menjawab soal keliling dan luas bangun datar.

\section{Kesulitan Siswa dalam Penggunaan Konsep}

Pemahaman konsep dalam matematika merupakan kemampuan pertama yang diharapkan dapat tercapai dalam tujuan pembelajaran matematika (Ningsih, 2016) maka pemahaman konsep sangat penting dikuasai oleh siswa dalam menghadapi variasi bentuk soal dalam matematika yang sedang dihadapi, pentingnya pemahaman konsep merupakan dasar dalam memperoleh hasil belajar yang diharapkan, adapun penggunaan konsep dalam matematika yaitu terkait dengan memahami dan membedakan kata, simbol dan tanda (Novitasari, 2016), akan tetapi kesulitan dalam penggunaan konsep sering terjadi, hal tersebut disebabkan karena proses pembelajaran matematika belum bermakna, sehingga pemahaman siswa tentang konsep matematika sangat lemah (Soviawati, 2011). Adapun kesulitan penggunaan konsep matematika pada penelitian ini adalah siswa tidak memperhatikan satuan keliling dan luas, mereka tidak mencantumkan satuannya, bahkan ada beberapa siswa yang menggunakan satuan keliling sebagai satuan luas, kesalahan ini juga disebut dengan kesalahan fakta (Lestari et al., 2016) hal ini dilatarbelakangi oleh ketidakmampuan siswa untuk menyatakan arti dari istilah yang mewakili konsep bangun datar tersebut atau menurut (Fatahillah et al., 2017) bahwa siswa belum memahami cara membaca satuan dengan benar.

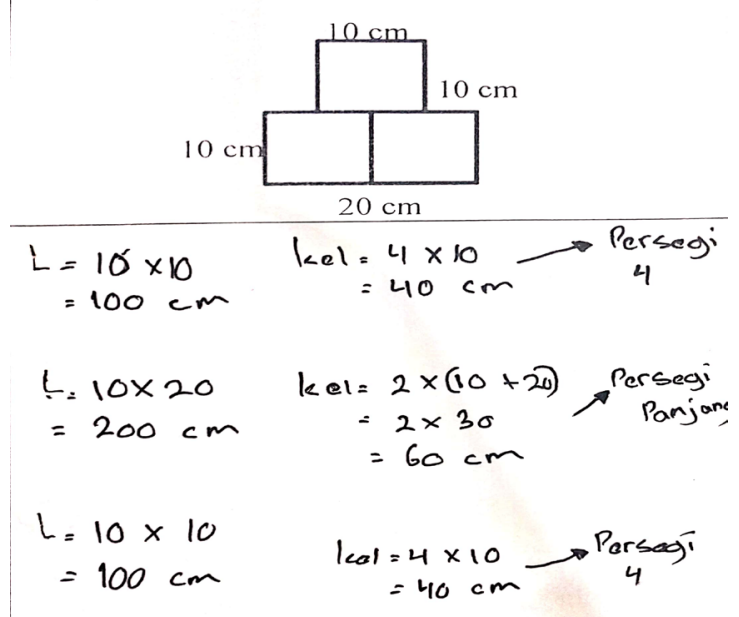

Gambar 2. Siswa keliru dalam mencantumkan satuan luas bangun datar 
Berdasarkan hasil wawancara yang dilakukan dengan siswa HSA diperoleh bahwa siswa mengalami kesulitan dalam menyatakan simbol satuan pada keliling dan luas.

Peneliti : Coba sekarang perhatikan jawaban kamu, kamu menjawab satuan luas adalah centimeter, benar?

Siswa HSA : lya pak benar.

Peneliti : Kalau satuannya keliling sama atau beda?

Siswa HSA : eh saya lupa pak, eee itu harusnya centimeter pangkat 2.

Peneliti : Kalau keliling satuannya apa?

Siswa HSA : itu pak, kalau keliling satuannya centimeter, saya suka lupa pak.

Kesulitan berikutnya adalah terkait dengan penggunaan rumus atau cara dalam mencari keliling bangun datar, siswa belum memahami konsep keliling, siswa cenderung menjawab bahwa dalam mencari keliling bangun datar diatas dengan mengalikan sisisisinya $(K=10 \times 10)$, padahal jika kita lihat bahwa ini merupakan rumus dari luas persegi $(L=$ Sisi $\times$ Sisi $)$, kesulitan ini dilatarbelakangi karena ketidakmampuan siswa untuk mengingat suatu kondisi yang cukup bagi suatu objek untuk dinyatakan dengan istilah yang mewakili dari konsep keliling dan luas bangun datar tersebut. Siswono (2008) menjelaskan bahwa siswa yang memiliki tingkat berfikir kreatif rendah biasanya sulit untuk mengingat rumus termasuk dalam bangun datar.

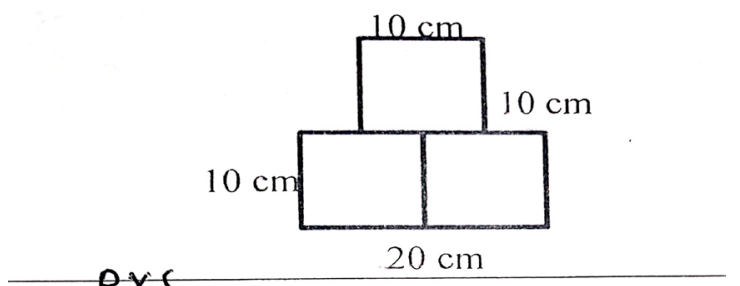

$\mathrm{kel}=10 \times 20=200$

-

$\mathrm{kel}=10 \times 10=100$

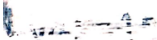

$k e l=20 \times 20=900$

Gambar 3. Kesulitan siswa dalam menginterpretasikan bentuk soal
Berdasarkan hasil wawancara yang dilakukan dengan siswa PM diperoleh bahwa siswa mengalami kesulitan dalam memahami sebuah konsep dari keliling, siswa sudah memahami bahwa panjang sisi-sisi terluar dari bangun datar adalah keliling, akan tetapi dalam mencari kelilingnya siswa justru mengalikan sisi-sisinya.

\begin{tabular}{|c|c|}
\hline Peneliti & $\begin{array}{l}\text { : nih yah, darigambarini kamu } \\
\text { taungga kelilingnya?(sambil } \\
\text { memperlihatkan gambar } \\
\text { soal geometri) }\end{array}$ \\
\hline Siswa PM & $\begin{array}{l}\text { yang ini pak! (sambil } \\
\text { menunjuk bagian sisi-sisi } \\
\text { bangun datar tersebut) }\end{array}$ \\
\hline ent & : Ini caranya dikali? \\
\hline Siswa PM & : eеe... iya pak! \\
\hline Peneliti & $\begin{array}{l}\text { : nih kalau kamu disuruh } \\
\text { menghitung langkah kaki, } \\
\text { ini 10 langkah, } 10 \text { langkah, } \\
\text { 10 langkah, } 10 \text { langkah } \\
\text { (sambil menggambar }\end{array}$ \\
\hline & $\begin{array}{l}\text { bentuk persegi), berapa } \\
\text { jumlah langkah dalam } \\
\text { mengelilingi ini! }\end{array}$ \\
\hline
\end{tabular}

Siswa PM : 40 pak!

Peneliti : jadi cara mencari keliling gimana?

Siswa PM : ditambahin.

\section{Kesulitan Siswa dalam Penggunaan Prinsip}

Penggunaan prinsip dalam pembelajaran matematika merupakan aspek yang sangat penting untuk dikuasai siswa, karena aspek tersebut sangat berkaitan dengan cara siswa dalam menyelesaikan suatu masalah, menurut Cooney (Yusmin, 2016) bahwa penggunaan prinsip dalam pembelajaran matematika meliputi kegiatan penemuan, mencari faktor yang relevan, dan menyimpulkan sebuah arti sampai menerapkan sesuatu yang mereka temukan. Kesulitan yang ditemukan dalam penelitian ini adalah siswa sudah memahami prinsip materi terkait dengan keliling dan luas, akan tetapi mereka tidak dapat menyelesaikan masalah yang diberikan, hal ini sesuai dengan pendapat Nurhamsiah et al 
(2016) bahwa mereka tidak dapat mengutarakan arti dan menerapkan prinsip yang ada. Selain itu, kesulitan yang ditemukan terkait dengan penggunaan prinsip adalah sulitnya siswa dalam menginterpretasikan bentuk soal yang telah disajikan, siswa juga merasa kebingungan dengan bentuk soal yang ada. Siswa juga tidak mampu menguraikan kedalam tiap-tip bangun datar yang terpisah untuk dapat mencari luas bangun datar diatas, padahal jika kita perhatikan, untuk mencari luas bangun datar diatas bisa di uraikan menjadi dua cara, pertama adalah 3 buah persegi, kedua adalah gabungan dari persegi di bagian atas dan persegi panjang dibagian bawah, hal ini bisa dilatarbelakangi karena ketidakmampuan siswa dalam menentukan faktor yang relevan yang terdapat pada gambar bangun datar, sehingga hal ini mengakibatkan ketidakmampuan siswa dalam mengabstraksikan pola-pola bangun datar dari soal tersebut. Hal ini juga didukung oleh Purbaningrum (2019) yang menyatakan bahwa kesulitan penggunaan prinsip ditandai dengan kesulitan siswa dalam melakukan kegiatan penemuan tentang sesuatu dan kesulitan menentukan faktor yang relevan dan akibatnya tidak mampu mengabstraksikan pola-pola.

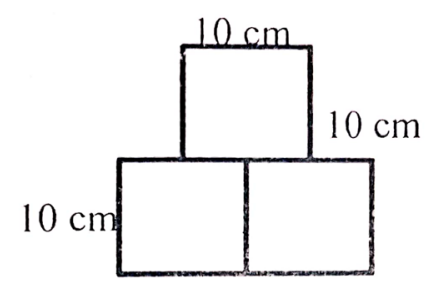

$20 \mathrm{~cm}$

\section{LUAS $=20 \times 10$}

$$
=200
$$

$$
\begin{aligned}
\text { Keling } & =2 \times(20+10) \\
& =60
\end{aligned}
$$

Gambar 4. Kesulitan siswa dalam menginterpretasikan bentuk soal

Berdasarkan hasil wawancara yang dilakukan dengan siswa CFA diperoleh bahwa siswa tersebut mengalami kesulitan dalam memahami pola-pola yang ada didalam soal.

Peneliti : kamu tadi menghitung keliling dan luas yang mana?

Siswa CFA :yang inipak! (Sambil menunjuk ke gambar persegi panjang)

Peneliti : Ko yang atasnya gak dihitung?

Siswa CFA : duuh, bingung pak... soalnya belum diajarin kaya gini!

Selanjutnya, ada beberapa siswa yang mampu mengabstraksikan bagian pola yang terdapat pada bangun datar, namun mereka tidak mampu untuk menyimpulkan terhadap apa yang mereka sedang cari tahu, yaitu mencari keliling dan luas gabungan bangun datar. Menurut Cooney (Yusmin, 2016) bahwa siswa memang sudah dapat menyatakan suatu prinsip akan tetapi mereka tidak dapat mengutarakan artinya, sehingga mengakibatkan mereka tidak dapat menerapkan prinsip tersebut.

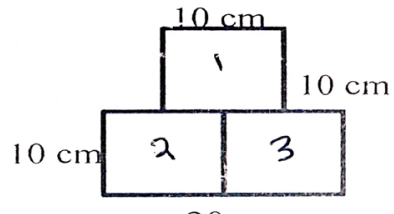

$20 \mathrm{~cm}$

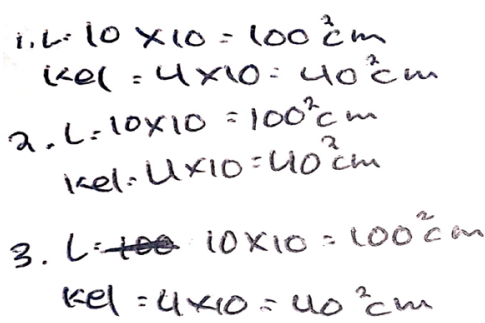

Gambar 5. Kesulitan siswa dalam menyimpulkan jawaban

Berdasarkan hasil wawancara yang dilakukan dengan siswa AR diperoleh bahwa siswa mengalami kesulitan dalam mengutarakan arti soal yang telah disajikan sehingga tidak mampu dalam menyimpulkan akhir jawaban.

Peneliti : coba perhatikan, ini luasnya ada 3 ?

Siswa AR : iya pak, luas yang ini, ini sama ini! (Sambil menunjuk ke gambar 
bangun datar)

Peneliti : kenapa gak dijumlahin?

Siswa AR : oh dijumlahin pak, kirain satu satu.

\section{Kesulitan Siswa dalam Menyele-} saikan Masalah-masalah Verbal

Masalah yang berkaitan dengan verbal sangat berkaitan dalam memahami berbagai istilah-istilah khusus, sehingga kemampuan dalam memahami berbagai istilah sangat penting dikuasai siswa dalam menyelesaikan berbagai masalah. Pada penelitian ini ditemukan kesulitan siswa yang berkaitan dengan masalah verbal, menurut Abrar (2018) kesulitan ini sering muncul disebabkan ketidakmampuan siswa dalam menggunakan konsep dan prinsip matematika. Adapun kesulitannya adalah ketidakmampuan siswa dalam memahami konteks soal yang disajikan, dalam memahami materi geometri siswa masih kesulitan dalam menerapkan rumus-rumus, memahami teorema-teorema, bahkan yang paling utama siswa masih mengalami kesulitan dalam memahami permasalahan dalam suatu soal (Sholihah \& Afriansyah., 2017). Selain itu, Menurut Suryadi (2010) bahwa ketika siswa dihadapkan pada permasalahan yang berbeda dengan biasanya, maka kemungkinan besar kesulitan yang tidak diharapkan akan muncul, hal inilah yang terjadi pada siswa dalam menjawab soal tersebut.
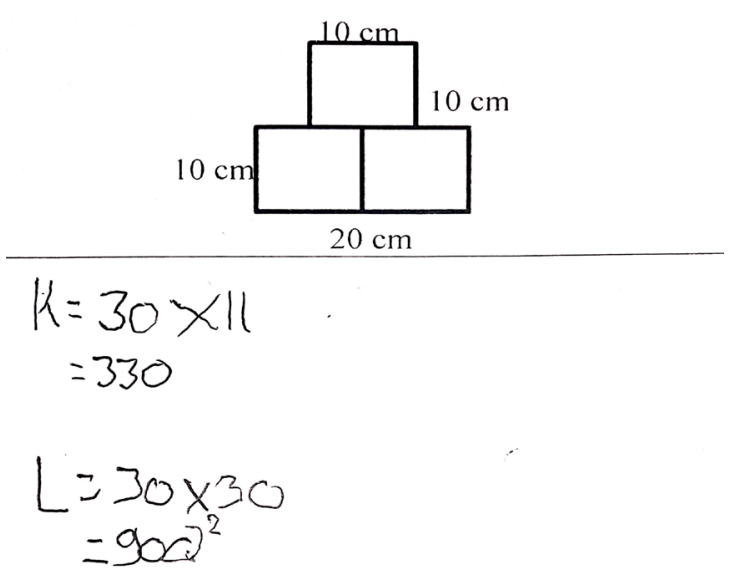

Gambar 6. Kesulitan siswa dalam memahami materi geometri
Berdasarkan hasil wawancara yang dilakukan dengan siswa KSN diperoleh bahwa siswa mengalami kesulitan dalam memhami materi geometri sehingga hal ini mengakibatkan ketidakmampuan siswa dalam menjawab soal yang telah disediakan.
Peneliti : ini zo dikali 11 dari mana, terus 30 dikali zo dari mana?

Siswa KSN : gak tau pak.

Peneliti : kamu materi ini paham gak?

Siswa KSN : enggak pak, pusing sama pelajaran matematika.

\section{SIMPULAN}

Berdasarkan hasil analisis data yang telah dijelaskan, maka dapat diambil kesimpulan bahwa siswa mengalami kesulitan belajar dalam materi geometri, ini terlihat dari presentase hasil belajar siswa yang menjawab keliling bangun datar dengan benar adalah 15,3 $\%$ dan menjawab luas bangun datar dengan benar adalah 3,8\%. Kesulitan-kesulitan yang dihadapi siswa diantaranya adalah (1) kesulitan siswa dalam penggunaan konsep yaitu ketidak mampuan siswa dalam menyatakan arti dari istilah yang mewakili konsep bangun datar dan ketidakmampuan siswa dalam mengingat suatu kondisi yang cukup bagi suatu objek untuk dinyatakan dengan istilah yang mewakili dari konsep keliling dan luas bangun datar. (2) kesulitan siswa dalam penggunaan prinsip yaitu ketidakmampuan siswa dalam menentukan faktor yang relevan yang terdapat pada gambar bangun datar dan kesulitan siswa dalam memahami arti dari prinsip yang telah mereka temukan yang mengakibatkan mereka tidak mampu menerapkan prinsip tersebut dan, (3) kesulitan siswa dalam menyelesaikan masalah-masalah yang berkaitan dengan verbal adalah ketidakmampuan siswa dalam menggunakan konsep dan prinsip pada materi bangun datar.

\section{REFERENSI}

Abrar, A. I. P. (2018). Kesulitan Siswa SMP Belajar Konsep Dan Prinsip Dalam Matematika. AlKhwarizmi: Jurnal Pendidikan Matematika Dan Ilmu Pengetahuan Alam, 2(1), 59-68. https://doi. org/10.24256/jpmipa.v2i1.102

Arikunto, S. (2013). Prosedur Penelitian Suatu Pendekatan Praktik. Jakarta: Rineka Cipta. 
Cherif, A. H., Gialamas, S., \& Stamati, A. (2017). Developing Mathematical Knowledge and Skills through the Awareness Approach of Teaching and Learning. Journal of Education and Practice, 8(13), 108132. www.iiste.org

Creswell, J. W. (2015). Penelitian Kualitatif \& Desain Riset. Yogyakarta: Pustaka Pelajar.

Fasha, A., Johar, R., \& Ikhsan, M. (2018). Peningkatan Kemampuan Pemecahan Masalah dan Berpikir Kritis Matematis Siswa melalui Pendekatan Metakognitif. Jurnal Didaktik Matematika, 5(2), 53-64. https://doi.org/10.24815/jdm.v5i2.11995

Fatahillah, A., N.T, Y. F. W., \& Susanto. (2017). Analisis Kesalahan Siswa dalam Menyelesaikan Soal Cerita Matematika berdasarkan Tahapan Newman Beserta Bentuk Scaffolding yang diberikan. Kadikma, 8(1), 40-51.

Fauzi, K. M. A., Dirgeyase, I. W., \& Priyatno, A. (2019). Building Learning Path of Mathematical Creative Thinking of Junior Students on Geometry Topics by Implementing Metacognitive Approach. In ternational Education Studies, 12(2), 57. https:// doi.org/10.5539/ies.v12n2p57

Gravemeijer, K., Stephan, M., Julie, C., Lin, F. L., \& Ohtani, M. (2017). What Mathematics Education May Prepare Students for the Society of the Future? International Journal of Science and Mathematics Education, 15, 105-123. https://doi. org/10.1007/s10763-017-9814-6

Hill, H. C., Blunk, M. L., Charalambous, C. Y., Lewis, J. M., Phelps, G. C., Sleep, L., \& Ball, D. L. (2008). Mathematical knowledge for teaching and the mathematical quality of instruction: An exploratory study. Cognition and Instruction, 26(4), 430-511. https://doi.org/10.1080/07370000802177235

Jupri, A. (2017). From geometry to algebra and vice versa: Realistic mathematics education principles for analyzing geometry tasks. AIP Conference Proceedings, 1830. https://doi. org/10.1063/1.4980938

Lestari, A. P., Hasbi, M., \& Lefrida, R. (2016). Analisis Kesalahan Siswa Kelas Ix Dalam Menyelesaikan Soal Cerita Keliling Dan Luas Lingkaran Di Smp Al-Azhar Palu. Jurnal Elektronik Pendidikan Matematika Tadulako, 3(4), 373-385.

Lestari, K. E., \& Mokhamad Ridwan Yudhanegara. (2015). Penelitian Pendidikan Matematika. Bandung: Refika Aditama.

MdYunus, A. S., Ayub, A. F. M., \& Hock, T. T. (2019). Geometric thinking of Malaysian elementary school students. International Journal of Instruction, 12(1), 1095-1112. https://doi.org/10.29333/ iji.2019.12170a

Mufarizuddin. (2018). Analisis Kesulitan Pembelajaran Matematika Siswa Kelas V Sd Negeri 012 Bangkinang Kota. Journal on Education, 1(1), 40-47.

Muhassanah, N., Sujadi, I., \& Riyadi. (2014). Analisis Keterampilan Geometri Siswa Dalam Memecahkan Masalah Geometri Berdasarkan Tingkat Berpikir Van Hiele. Jurnal Elektronik Pembelajaran Matematika, 2(1), 54-66. http://jurnal.fkip.uns. ac.id
Ningsih, Y. L. (2016). Kemampuan Pemahaman Konsep Matematika Mahasiswa Melalui Penerapan Lembar Aktivitas Mahasiswa (LAM) Berbasis Teori APOS Pada Materi Turunan. Edumatica, 6(1), 1-8. https://doi.org/10.1063/1.4944618

Noto, M. S., Priatna, N., \& Dahlan, J. A. (2019). Mathematical proof: The learning obstacles of pre-service mathematics teachers on transformation geometry. Journal on Mathematics Education, 10(1), 117-125. https://doi.org/10.22342/ jme.10.1.5379.117-126

Novitasari, D. (2016). Pengaruh Penggunaan Multimedia Interaktif Terhadap Kemampuan Pemahaman Konsep Matematis Siswa. FIBONACCI: Jurnal Pendidikan Matematika Dan Matematika, 2(2), 8. https://doi.org/10.24853/fbc.2.2.8-18

Nur, A. S., \& Palobo, M. (2018). Profil Kemampuan Pemecahan Masalah Matematika Siswa Ditinjau dari Perbedaan Gaya Kognitif dan Gender. Kreano, 9(2), 139-148. https://doi.org/http://dx.doi. org/10.15294/kreano.vgi2.15067

Nurhamsiah, N., Halini, H., \& Ahmad, D. (2016). Analisis Kesulitan Siswa dalam Mempelajari Bentuk Aljaar Berkaitan dengan Konsep dan Prinsip di SMP. Jurnal Pendidikan Dan Pembelajaran Untan, 5(2).

Nurhasanah, F., Kusumah, Y. S., \& Sabandar, J. (2017). Concept of Triangle: Examples of Mathematical Abstraction in Two Different Contexts. International Journal on Emerging Mathematics Education, 1(1), 53. https://doi.org/10.12928/ijeme. v1i1. 5782

Panaoura, A. (2014). Using representations in geometry: a model of students' cognitive and affective performance. International Journal of Mathematical Education in Science and Technology, 45(4), 498-511. https://doi.org/10.1080/002073 9X.2013.851804

Permendikbud Nomor 37 Tahun 2018 tentang Perubahan atas Permendikbud Nomor 24 Tahun 2016 tentang Kompetensi Inti dan Kompetensi Dasar Pelajaran Pada Kurikulum 2013 pada Pendidikan Dasar dan Pendidikan Menengah

Purbaningrum, K. A. (2019). Analisis Kesulitan Mahasiswa dalam Memahami Materi Kontinuitas Fungsi Mata Kuliah Kalkulus Diferensial. Math Didactic: Jurnal Pendidikan Matematika, 5(2), 199-209. https://doi.org/10.1017/CBO9781107415324.004

Ricks, T. E. (2009). Mathematics Is Motivating. Mathematics Educator, 19(2), 2-9.

Rofii, A., Sunardi, S., \& Irvan, M. (2018). Characteristics of Students' Metacognition Process At Informal Deduction Thinking Level in Geometry Problems. International Journal on Emerging Mathematics Education, 2(1), 89. https://doi. org/10.12928/ijeme.v2i1.7684

Seah, R. (2015). Reasoning with geometric shapes Visualisation as a tool for geometric reasoning. Amt, $71(2), 4^{-11 .}$

Sholihah, S. Z., \& Afriansyah., E. A. (2017). Analisis Kesulitan Siswa dalam Proses Pemecahan Masalah Geometri Berdasarkan Tahapan Berfikir Van 
Hiele. Jurnal "Mosharafa," 6(2), 287-298.

Siswono, T. Y. E. (2008). Proses Berfikir Kreatif siswa dalam Memecahkan dan Mengajukan Masalah Matematika. Jurnal Ilmu Pendidikan, 15(1), 6068.

Soviawati, E. (2011). Pendekatan Matematika Realistik (PMR) untuk Meningkatkan Kemampuan Berpikir Siswa di Tingkat Sekolah Dasar. Jurnal Edisi Khusus, 2, 79-85.

Suryadi, D. (2010). Menciptakan Proses Belajar Aktif: Kajian dari Sudut Pandang Teori Belajar dan Teori Didaktik. 1-16. https://doi.org/10.1016/j.solmat.2005.04.015

Turmudi. (2008). Landasan Filsafat dan Teori Pembelajaran Matematika (Berparadigma Eksploratif dan Investigatif). Jakarta: Leuseur Cipta Pustaka.

Unlu, M., Ertekin, E., \& Dilmac, B. (2017). Predicting Relationships between Mathematics Anxiety, Mathematics Teaching Anxiety, Self-efficacy Beliefs towards Mathematics and Mathematics Teaching. International Journal of Research in Education and Science, 636-636. https://doi. org/10.2189o/ijres.328096

Yusmin, E. (2016). Kesulitan Belajar Siswa pada pelajaran Matematika (Rangkuman Dengan Pendekatan Meta-Ethnography). Jurnal Visi Ilmu Pendidikan, 9(1), 2119-2136. 